\section{Os novos cães de guarda}

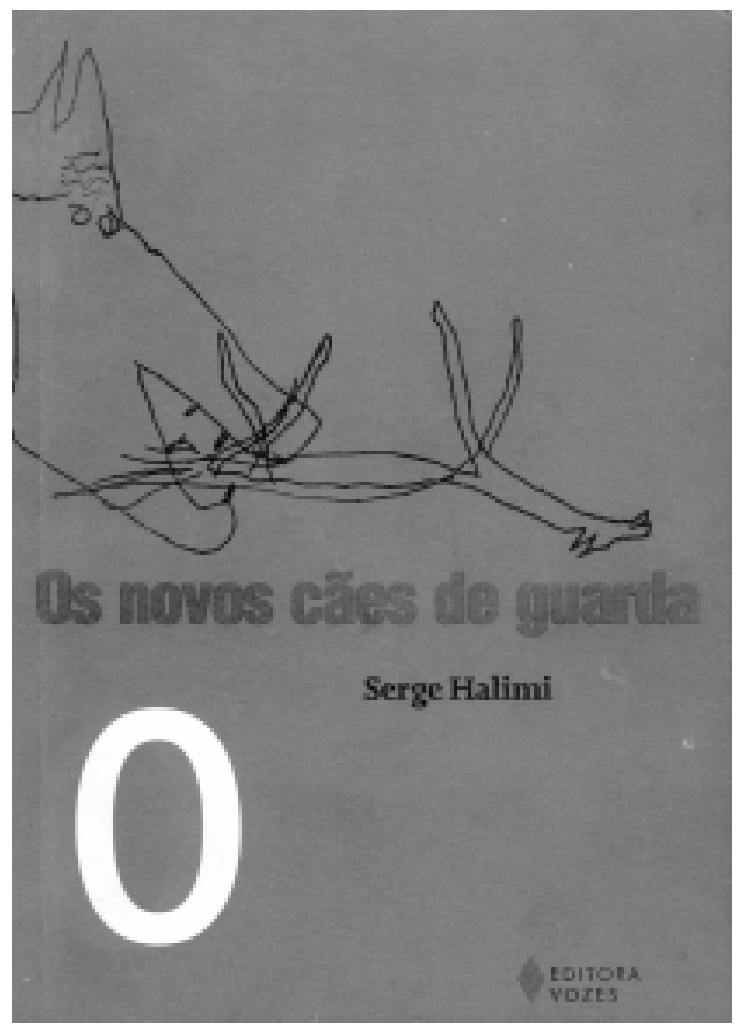

AntonioHohlfeldt

Prof. Coordenador do PPGC- FAMECOS/PUCRS
Serge Halimi PRETENDE denunciar, em Os novos cães de guarda, o que chama de jornalismo de reverência, que seria uma característica do atual jornalismo francês. Para ele, existe uma estreita relação entre o jornalismo e o poder, que se traduz na formação de uma espécie de máfia, integrada por alguns destacados profissionais que não apenas ganham fantásticas fortunas em sua profissão, quanto se repartem restritivamente os espaços, os elogios e, evidentemente, os interesses dos diferentes espaços da mídia francesa.

Retomando uma expressão de Paul Nizan, a respeito de filósofos que, segundo ele, não realizavam bem a sua missão interrogativa, Serge Halimi arvora-se numa espécie de corregedor da mídia de seu país, atacando especialmente as práticas de alguns dos nomes de maior referencialidade na mídia francesa, como Alain Peyrefite, Alain Touraine, Christine Okrent, André Rousselet, J. Clément, Alain Duhamel, Michel Field, Alain Minc, Anne Sinclair, Jean-Marie Cavada e outros tantos.

Para ele, existe uma relação direta entre o poder econômico e os jornalistas de grande notoriedade. Como, por outro lado, também existe uma relação entre o poder econômico e a política, termina Halimi por pretender denunciar a relação entre o poder econômico, $\mathrm{o}$ poder político e a mídia, o que, segundo ele, é antiético.

Ora, há muito tempo - os teóricos dizem que pelo menos desde o início do século XIX - que esta situação existe. Ou seja, a partir do momento em que a informação se tornou uma mercadoria, estreitaram-se os laços entre o poder econômico e o poder político. Basta ler, dentre outros estudiosos brasileiros, Ciro Marcondes Filho (Imprensa e capitalismo, S. Paulo, Kairós, 1984), para se ter evidenciada esta realidade. Ela pode não ser a ideal, e por certo não o é. Mas daí a pretender o autor deste livro estar a denunciar uma determinada realidade, como se ela fosse novidade, chega quase ao ridículo. Das duas 
uma: ou Halimi não se dá conta do mundo em que vive ou então continua sonhando com determinadas utopias inexistentes no mundo capitalista.

Para robustecer sua denúncia, Halimi pretende fazer comparações entre as práticas francesas e norte-americanas, concluindo que existiria maior autonomia na mídia dos Estados Unidos do que na francesa. É provável que os administradores da mídia norte-americana tenham maior cuidado com as emissões e as informações que divulgam. Mas não se pode acreditar, de boa fé, que as relações entre poder econômico e poder político, refletindo-se sobre a relação destes com os jornalistas, seja diversa da realidade que ocorre na França. Observe-se que a administração redacional toma muito cuidado com o que permite ser publicado e a primeira emenda à Constituição norte-americana, se garante a absoluta liberdade de imprensa, obriga igualmente a uma responsabilidade radical dos proprietários de uma empresa de comunicação em relação ao que divulgam. Observe-se o famoso relato de Bob Woodward e Carl Bernstein a respeito do Caso Watergate. No entanto, todos conhecemos a profunda centralização, os oligopólios formados pela chamada indústria cultural, na antiga acepção de Adorno-Horkheimer, atualizada enquanto indústria de consciências, por Enzensberger, focalizada em obra muito bem pesquisada de Armand Mattelart na década de 70 (As multinacionais da cultura, Rio de Janeiro, Civilização Brasileira, 1976).

A impressão que se tem é que Serge Halimi não conseguiu espaço em nenhum segmento, nem mesmo no socialista, que denuncia veementemente, reduzindo às mesmas práticas tanto o direitista Chirac quanto o socialista Mitterrand. Na verdade, o discurso trotskista de Halimi só tem uma vantagem: mostra o ridículo de certas práticas entre os principais jornalistas franceses, de autolouvação e entrecitações que, evidentemente, devem ser repudiadas pelos espectadores e leitores destes profissionais em geral. Mas ele próprio acaba por diminuir a força de sua denúncia quando reconhece que alguns dos pretensamente denunciados nem sempre permanecem com as vantagens condenadas, bastando citar-se a situação de Christine Okrent, demitida justamente por quebrar algumas das regras vigentes na mídia francesa.

Bem embasado teoricamente, mas sob uma ótica não sei se ingênua ou apenas escandalosa, o livro de Serge Halimi esgota-se em si mesmo. Sob a capa do discurso acadêmico, tingido de ética indignada, nada mais encontramos que um punhado de fofocas encontráveis até mesmo em publicações como a Caras brasileira. Se se quiser, de fato, discutir e aprofundar as questões éticas desta convivência ou, mesmo, desta conivência, talvez seja melhor ler o norte-americano John Hulteng (Os desafios da comunicação: problemas éticos, Florianópolis, UFSC, 1990), Claude-Jean Bertrand (A deontologia das mídias, Bauru, EDUSC, 1999) ou ainda Daniel Cornu (Ética da informação, Bauru, EDUSC, 1998), menos panfletários e mais objetivos em suas análises.

HALIMI, Serge - Os novos cães de guarda, Petrópolis, Vozes, 1998, 150 páginas 